Akademik Siyer Dergisi / Journal of Academic Sirah

e-ISSN: 2687-5810

Y11 / Year: 3, Say1/ Issue: 5, Sayfa / Page: 70-90

\title{
Râvî Tenkidinde Objektiflik Üzerine Bir Değerlendirme
}

An Evaluation of Objectivity in Rāwī's Criticism

\author{
Veli Aba \\ Doç. Dr., KSÜ İlahiyat Fakültesi, Hadis Ana Bilim Dalı \\ Assoc. Prof. Dr., KSU Faculty of Theology, Department of Hadith \\ Kahramanmaraş / Turkey \\ vaba75@hotmail.com \\ orcid.org/0000-0003-4558-038X \\ Nuray Korkmaz \\ Y1 Öğrencisi, KSÜ, Hadis Ana Bilim Dalı \\ GS., KSU, Department of Hadith \\ Kahramanmaraş / Turkey \\ nrykrkmz2020@hotmail.com \\ orcid.org/0000-0002-1024-7133
}

\section{Makale Bilgisi / Article Information}

Makale Türü: Araştırma Makalesi / Article Type: Research Article Geliş Tarihi: 29 Eylül 2021 / Date Received: 29 September 2021

Kabul Tarihi: 20 Aralık 2021 / Date Accepted: 20 December 2021

Yayın Tarihi: 1 Ocak 2022 / Date Published: 1 January 2022

Yayın Sezonu: Ocak 2022 / Pub Date Season: January 2022

Atıf: Aba, Veli-Korkmaz, Nuray. "Râvî Tenkidinde Objektiflik Üzerine Bir Değerlendirme”. Akademik Siyer Dergisi 5 (Ocak 2022), 70-90.

Citiation: Aba, Veli-Korkmaz, Nuray. "An Evaluation of Objectivity in Rāwī's Criticism". Journal of Academic Sirah 5 (January 2022), 70-90.

https://doi.org/ 10.47169/samer.1002400

İntihal: Bu makale, iTenticate yazılımınca taranmıştır. İntihal tespit edilmemiştir.

Plagiarism: This article has been scanned by iTenticate. No plagiarism detected.

web: http:// dergipark.gov.tr/samer e-mail: akademiksiyerdergisi@ksu.edu.tr

Copyright (C) Published by KSÜ Siyer-i Nebi Araştırmaları Uygulama ve Araştırma Merkezi

KSU Sirah Researches Application and Research Center

Kahramanmaraş 46100 Turkey

Bütün hakları saklıdır. / All right reserved. 
71 Veli Aba - Nuray Korkmaz / Râvî Tenkidinde Objektiflik Üzerine Bir Değerlendirme / An Evaluation of Objectivity in Rāwī's Criticism

\title{
$\ddot{O} z$
}

Râvî tenkidi, rivayetlerin sahihliği ve hadislerin Hz. Peygamber'e aidiyetinin tespit edilmesi hususunda hiç şüphesiz ki en önemli kilometre taşlarından birini oluşturmaktadır. Bu bağlamda hadis münekkitlerinin cerhta'dîl faaliyetleri esnasında sergiledikleri tutumların önemi îzahtan vârestedir. Münekkitlerin tenkit kriterlerinde ulaştıkları maksimum objektiflik seviyesi bu faaliyeti daha da sağlamlaştırmakta ve hedeflenen seviyeye yaklaşılmaktadır. Bu çalışmada öncelikle konu ile doğrudan alakalı olan tenkit, objektiflik, tarafsızlık (nesnellik), kavramları üzerinde durulmuştur. Aynı zamanda klasik ve çağdaş hadis eserlerinde yer alan cerhta'dîl, nakd, kritik/kritic, eleştiri, reddiye kavramları kaynak tarama yöntemi ile incelenmiştir. Elde edilen bulgular bir araya getirilerek râvî tenkidinde objektifliğin ne anlama geldiği ve ne ölçüde gerçekleştirilebildiği değerlendirilmiştir. Böylece İslâm dininin ikinci kaynağı mesâbesindeki sünnetin menşei olan hadis ilmine önemli bir katkıda bulunulması amaçlanmıştır.

Anahtar Kelimeler: Hadis, Râvî, Tenkit, Objektiflik, Nesnellik.

\begin{abstract}
The rāwī's criticism is undoubtedly one of the most important milestones in determining the belonging of the hadiths to the Prophet Muhammad. In this context, the importance of the attitudes of the hadith critics during the al-jarh wa-l-ta 'dil activities is unquestionable. The maximum objectivity achieved by the critics in the criticism criteria further strengthens this activity and approaches to the targeted level. In this study, the concepts of criticism, objectivity, and impartiality, which are directly related to the subject, were examined. At the same time, with the literature review, the concepts of jarh-ta 'dil, naqd, critic, criticism, and rejection in classical and modern hadiths were emphasized. The obtained findings were brought together to evaluate what objectivity means and to what extent it can be achieved in rāwī's criticism. Thus, it is aimed to make a significant contribution to the science of hadith, which is the origin of the sunnah that is the second source of Islam.
\end{abstract}

Keywords: Hadīth, Rāwī, Criticism, Objektivity, Impartiality. 


\section{GíRIŞ}

Yüce Allah, Kur'an-1 Kerim'i "apaçık"1 ifadesiyle vasfetmiş ve Hz. Peygamber'i de "insanlara kendilerine indirileni açılamakla"2 vazifelendirmiştir. Kur'an'ın bu apaçıklık vasfı sünnetin anlaşılmasına, dolayısıyla hadislerdeki verileri dikkate almaya bağlıdır. Hz. Peygamber de "Ben ancak (sizin gibi) bir beşerim. Size dininizden bir şey emrettiğim zaman onu yapını. Re'y olarak bir şey emrettiğgimde ise ben bir beşerim." 3 buyurarak tebliğ yükümlülüğü dışındaki tasarruflarının tenkide açık olduğunu ifade etmiş olmaktadır. İşte müslümanlar birbirleriyle münâsebetlerinde İslamiyet'ten aldıkları bu şiarlara istinâden hak ve hakikat adına doğru bildiklerini Peygamberleri dâhil muhatapları kim olursa olsun bildirmekten ve tenkitlerini zamanında yapmaktan asla geri durmamışlardır. ${ }^{4}$ Doğruya ulaşma gayesiyle sarf edilen bu çabaların ürünü olarak cerh-ta' dîl ilmi teşekkül etmiştir. Cerh-ta' dîl birçok çalışmaya konu olmuş ve farklı boyutlarıyla incelemeye tabi tutulmuştur. ${ }^{5}$ Tespit edebildiğimiz kadarıyla cerh-ta' dîl literatürü içerisinde önemli bir konuma sahip olan râvî tenkidinde objektiflik konusu müstakil ve geniş bir çalışmayla ele alınmaya muhtaçtır. Her ne kadar özellikle râvî ile ilgili bir konuda yapılan çalışmada objektiflik belli bir başlık altında kısa olarak işlense de alanla ilgili yapılan kısmî çalışmalarda öznelliğin ön plana çıkarıldığı ve nesnelliğin ise göz ardı edildiği tespit edilmiştir. ${ }^{6}$ Râvî tenkidinde nesnelliği vurgulayan önemli bir çalışma olarak Veli Aba tarafından yapılan ve yayınlanan "Duygusal Yakınlık Bağlamında Nesnel Cerh Uygulama Örnekleri (Baba-Oğul/Hoca-Talebe Özelinde)"7 adlı makale örnek verilebilir. Duygusal yakınlık bağlamında ele alınan bu makaleden mülhem olarak râvî tenkidinde objektiflik meselesinin geniş çaplı araştırma ve değerlendirmelere ihtiyaç duyduğu kanaati bizde hâsıl olmuştur. Bu gerekçe ile bahse konu başlık ele alınırken subjektifliğe sebep olabilecek spesifik durumlar ve örnekler irdelenmiş, nesnel tenkit örnekleri ile mukayese edilerek konu değerlendirilmeye çalışılmıştır. ${ }^{8}$

${ }^{1}$ Kur'ân Yolu (Erişim 9 Mayıs 2021), el-Kasas 28/2; Yâsîn 36/69; ez-Zuhruf 43/2; ed-Duhân 44/2.

2 en-Nahl 16/44.

3 Ebü'l-Hüseyn Müslim b. el-Haccâc el-Kuşeyrî, el-Câmiu's-sahîh, thk. Muhammed Fuâd Abdulbâkî (Beyrût: Dârü İhyâi't-Turâsi'l-Arabî, ts.), "Fedâil", 38.

${ }^{4}$ Mehmed Said Hatiboğlu, İslami Tenkid Zihniyeti ve Hadis İlminin Doğuşu (Ankara: Otto Yayınları, 2016), 33.

${ }^{5}$ Abdullah Karahan, "Türkiye'de Cerh ve Ta'dîl ile Alakalı Yapılmış Çalışmalar", Uludağ Üniversitesi İlâhiyat Fakültesi Dergisi 13/2 (2004); Muhammed Mustafa el A'zam'î, Muhaddislerin Hadis Tenkit Yöntemi, çev. M. Enes Topgül - M. İkbal Aslan (İstanbul: Beka Yayınları, 2017); Salahattin Polat, Hadis Araştırmaları, Tarih, Usûl, Tenkid, Yorum (Kayseri: Kimlik Yayınları, 2017); Salahattin Polat vd., Hadis Araştırma ve Tenkit Kılavuzu (İstanbul: MÜ İlahiyat Fakuiltesi Vakfı Yayınları, 2018); Abdulfettâh Ebû Gudde, Hadis İlminde Cerh ve Ta'dîl, çev. Harun Reşit Demirel (Ankara: Takdim Yayınları, 2019); Abdulhay el-Leknevî, Hadis Değerlendirme Kriterleri, çev. Mahmut Yazıcı (Ankara: Takdim Yayınları, 2019); Halil İbrahim Turhan, Ricâl Tenkidinin Doğuşu ve Gelişimi, Hicrî ilk İki Asır (İstanbul: MÜ İlahiyat Fakültesi Yayınları, 2015); Muhammed Enes Topgül, Rivayetten Râviye, Cerh-Ta' dîl Hükümleri Nasıl Oluştu? (İstanbul: Marmara Üniversitesi İlahiyat Fakültesi Vakfı Yayinlar1, 2019).

6 Polat, Hadis Araştırmaları, 41-66; Bayram Kanarya, "Cerh-Ta'dîl Bağlamında İmam Şafiî̀ye Yöneltilen İthamlar", Hitit Üniversitesi İlahiyat Fakültesi Dergisi 16/31 (2017), 230-232.

7 Veli Aba, "Duygusal Yakınlık Bağlamında Nesnel Cerh Uygulama Örnekleri (Baba-Oğul/Hoca-Talebe Özelinde)", Din Bilimleri Akademik Araştırma Dergisi 16/2 (Haziran 2016), 125-156.

${ }^{8}$ Hâlihazırda konu ile alakalı daha geniş bir çalışmanın içerisinde olduğumuz için örnekleri sınırlandırarak vermeyi uygun gördük. 
73 Veli Aba - Nuray Korkmaz / Râvî Tenkidinde Objektiflik Üzerine Bir Değerlendirme / An Evaluation of Objectivity in Rāwī's Criticism

Subjektif eleştiri örnekleri incelendiğinde tarafsızlığa engel olan birçok durumun olduğu görülecektir. Şahsî anlaşmazlıkların etkisinde kalma, mezhep taassubu ve akide olarak muhalif olma, ${ }^{9}$ ön yargı ile hareket etme, hadis ilminde ihtisas sahibi olmama, yakınlık bağının bulunması, sosyal ve siyasî baskı/ korku belli başlı subjektif eleştiri örnekleri olarak verilebilir. ${ }^{10}$

Münekkitlerin râvîleri tenkit ederken tamamıla objektif bir tutum sergilediklerini kabul etmek elbette mümkün değildir. Buna mukabil mevcut subjektif tutumların da umuma hamledilmesinin hatalı bir yaklaşım tarzı olacağını belirtmek gerekir. Bütün bunların yanında dikkatle ve insaflı bir şekilde yapılacak araştırma ve incelemeler neticesinde belli oranda objektif tenkidin de mevcut olduğu ileride ele alacağımız konuyla ilgili özel başlıklar altında örneklerle ortaya konacaktır. Söz konusu değerlendirmelere geçmeden önce konu ile ilgili kavramlara yer vermekte fayda mülahaza edilmektedir.

\section{TENKİT}

نق-ق-د Tenkit kavramı Fransızların kullandığ1 critique kelimesine karşılık gelmektedir. Arapçada fiili tef'il babında kullanılmadığından bunun yerine نتقاد ve نتقاد kavramlarının kullanılması daha isabetli olacaktır.11 Sözlükte "oymak, kanatırcasına vurmak, yarmak, gagalamak, seçip almak, tartışmak,"12 manalarına gelen ن-ق-ن fiili mecaz olarak da "muhatabı eleştirel gözle fark ettirmeden incelemek"13 şeklinde kullanılmıştır. Zebîdî (öl. 1205/1791) bu kelimeyi "yılanın sokması"14 şeklinde tanımlamış, Ezherî (öl. 370/980) ise "görüş ayrılığ1" olarak tarif etmiştir.15 Ebü'd-Derdâ'dan (öl. 32/652 [?]) rivayet edilen bir hadiste ن-ق د fiili "ayıplamak, giybet etmek"16 şeklinde kullanılmıştır. Bu fiilden elde edilen ve tenkit karşılığında kullanılan النَُّْْ د "sahte paranın ayırt edilmesi” 17, "bir insanın peşin olarak para vermesi ve alması"18 gibi anlamlara gelmektedir. Terim olarak da "sahihini zayıfından ayırt etmek için hadisleri, özel lafızlarla cerhederek ya da tadil ederek hüküm vermek için râvîleri ve ehline mâlûm olan delilleri inceleyen ilimdir. ${ }^{19}$ Bu istılâhî anlamında da görüldüğü üzere tenkit, olumlu-olumsuz ayrımına gidilmeden yapılan değerlendirmeleri içermektedir. Fakat günümüzde

9 İbn Dakîkul'îd, Ebü'l-Feth Takıyyüddîn Muhammed b. Alî b. Vehb el-Kuşeyrî, el-ïktirâh fì beyâni'l-lstlâh ve mâ üdîfe ilâ zâlike mine'l-ehâdîsi'l-ma 'dûde mine's-sıhâh (Beyrût: Dârü'l-Kütübü'l-İlmiyye, ts), 58.

${ }^{10}$ Subjektiviteye sebep olan âmillerin sayısı daha da artırılabilir fakat tamamına yer vermek makalenin sınırını aşacağından bu kadarı ile iktifâ ettik.

11 Şemseddin Sâmi, Kâmûs-ı Türk̂̂, nşr. Ahmed Cevdet (Dersaadet: İkdâm Matbaası, 1317), "tenkid" 445; Tenkit kavramı hakkında daha fazla bilgi için bk. Hacer Gülşen, "Tenkit ve Edebi Tenkit" 3 (2003).

${ }^{12}$ Ebû Abdurrahman Halil b. Ahmed, Kitâbu'l-'Ayn, thk. Mehdî el-Mahzûmî - İbrahim es- Samerrâî (Dârü Mektebetü'l-Hilâl, ts), "nkd", 5/118-119; Ebû Mansûr Muhammed b. Ahmed b. Ezher, Tehzîbü'l-luga, thk. Muhammed Avz Mer'ab (Beyrût: Dâru İhyâi't-Turasi'l-Arabî, 2001), "nkd", 9/50; Muhammed Murtazâ ezZebîdî, Tâcü'l- 'arûs min cevâhiri'l-Kâmûs, thk. Mecmûa min Muhakkîkîn (b.y.: Dârul Hidâye, ts), "nkd", 9/230231.

${ }^{13}$ Zebîdî, "nkd", 9/230-231.

${ }^{14}$ Zebîdî, "nkd", 9/230-231; Cemâleddîn Muhammed b. Mükerrem b. Alî b. Ahmed el-Ensârî, Lisânü'l- 'Arab (Beyrût: Dârü Sadr, ts), "nkd", 3/426.

${ }^{15}$ Ezherî, "nkd", 9/50.

${ }^{16}$ Ezherî, "nkd", 9/51; Zebîdî, "nkd", 9/234-235.

${ }_{17}^{17}$ Halil b. Ahmed, "nkd", 5/118; Ezherî, "nkd", 9/50; Zebîdî, "nkd", 9/230; İbn Manzur, "nkd", 3/425.

${ }^{18}$ Halil b. Ahmed, "nkd", 5/118; Ezherî, "nkd", 9/50.

${ }^{19}$ Ebû Dâvûd Süleymân b. el-Eş'as b. İshâk es-Sicistânî el-Ezdî, Su'âlâtu Ebî̀ 'Ubeyd Muhammed b. 'Alî b. 'Osmân el-Âcurrî Ebâ Dâvud es-Sicistanî fi'l-cerh ve't-ta'dîl, thk. Muhammed Ali Kâsım el-Ömerî (Medîne-i Münevvere: el-Camiatü'l İslâmiyye, 1403/1983), 45. 
anlam daralmasına uğrayıp sadece olumsuz değerlendirmeler için kullanılmaktadır. Yine aynı kökten türetilen الانتِقادُ ise "nakit olarak verilen parayı almak"20, "paranın hakikisini sahtesinden ayırt etmek"21 manalarına karşılık gelmektedir. Şemsettin Sami de bu kavramı şöyle açıklamaktadır: "Âsâr-1 edebiyye ve fennîyenin bîtarafâne nazâr-1 tedkîk ve muayeneden geçirilmesiyle bilmuhâkeme beyan-ı mütalaa edilmesidir." Bu açıklamada da câlib-i dikkattir ki 'tarafsızlık' aslında tenkidin mayasında vardır, tarafgirlik devreye girdiğinde ortada tenkit namına bir şey kalmaz. Tenkit, hadis ilminin omurgasıdır²2 ve bu ilmin dinamizmini sürdüren âb-1 hayat konumundadır.

\section{OBJEKTIFLIK}

Objektiflik kavramı Fransızca kökenli objectif (objektif) kelimesinden türetilmiş olup sözlükte; "nesnel olmak, tarafsız davranmak" anlamlarına"23 gelir. Bu tanımdan da anlaşıldığı gibi objektiflik, "nesnellik" ve "tarafsızlık" kavramlarılla yakından ilgilidir. Bu bakımdan bu kavramlara da değinilmesi önem arz etmektedir.

Nesnellik, "nesnel olma veya nesnelerin gerçeğine dayanma durumu"24 olarak ifade edilir. Genel kullanımıyla herkes için geçerli evrensel kabullere göre düşünüp hareket etmeyi, şahsî duyguları geri planda tutmayı ifade eden nesnellik, tarafsız bir değerlendirmenin ön koşuludur. Bir çalışmanın evrenselliği ve tarafsızlığı nesnellikle doğru orantılı olduğundan elde edilen başarı da bu iki koşula göre değerlendirilir.25 Tarafsızlık; sözlükte "tarafsız olma durumu, yansızlık, bîtaraflık" 26 şeklinde tanımlanmaktadır. Tarafsızlık, nesnellik ve objektiflik kavramları sözlük tanımlarından hareketle eş anlamlı olarak kullanılabileceğinden bu çalışmada söz konusu kavramlar birbirlerinin yerine kullanılmıştır.

\section{RÂVÎ TENKİDINDE OBJEKTIFLIKK SORUNU27}

İbn Salah'ın da ifade ettiği gibi hadis ilmi, takdire şâyân ahlak ve mizaç güzelliklerine tam anlamıla uyumlu; buna mukabil ayıplanan kusurlu ahlak ve mizaç çirkinliklerine tezat teşkil eden bir ilim olması hasebiyle asil bir ilimdir. Hadis ilmiyle ilgilenmek ve ondan faydalanmak isteyenlerin öncelikle niyetlerini ve ihlaslarını tashih etmeleri, kalplerini dünyevî kirlerden arındırmaları, makam ve mevki sevgisi ve hamakatten sakınmaları gerekmektedir. ${ }^{28} \mathrm{Bu}$ ilim içerisinde önemli bir konuma sahip olan tenkit faaliyeti de ciddî manada mesuliyet gerektirdiğinden cerh-ta'dîl âlimlerinin birtakım hususiyetlere sahip olmaları gerekmektedir. Münekkit âlimlerin taşıması zarûrî vasıflar şöyle sıralanabilir: Takva sahibi olmak, emin olmadan karar vermemek,

${ }^{20}$ Zebîdî, "nkd", 9/230.

${ }^{21}$ Mücteba Uğur, Ansiklopedik Hadis Terimleri Sözlüğü (Ankara: Türkiye Diyanet Vakfı, 2018), "intikad" 163.

22 Bekir Tatlı, "Hadis Usulünde Râvi ve Rical Tenkidinin Teolojik Temelleri", Çukurova Üniversitesi İlahiyat Fakültesi Dergisi (ÇÜIFD) 20/2 (2020), 421.

${ }_{23}^{3}$ İsmail Parlatır vd., Türkçe Sözlük (Ankara: Türk Dil Kurumu, 1998), "objektif" 2/1667.

${ }^{24}$ Parlatır vd., "nesnellik" 2/1647.

25 Umut Dağıstan, "Sosyal Bilimlerde Nesnellik Olgusu", Türk \& İslam Dünyası Sosyal Araştırmalar Dergisi /The Journal of Turk \& Islam World Social Studies 4/14 (Aralık 2017), 451.

26 Parlatır vd., "Tarafsızlık" 2/2137.

${ }^{27} \mathrm{Bu}$ çalışmada "objektiflik" kavramı, sözlüklerde geçen tanımları göz önünde bulundurularak aralarındaki anlam yakınlığı sebebiyle nesnellik ve tarafsızlık ile aynı manada kullanılmıştır.

${ }^{28}$ Ebû Amr Takıyyüddîn Osmân b. Salâhiddîn Abdirrahmân b. Mûsâ, Mukaddimetü İbni's-Salâh, thk. Nûreddin Itr (Sûriye - Beyrût: Dârü'l-Fikr - Dârü'l-Fikri'l-Muâsır, 1406/1986), 236. 
75 Veli Aba - Nuray Korkmaz / Râvî Tenkidinde Objektiflik Üzerine Bir Değerlendirme / An Evaluation of Objectivity in Rāwī's Criticism

sonuca ulaşana kadar titiz bir şekilde araştırma yapmaya devam etmek, ${ }^{29}$ duyulan haberlere karş1 ihtiyatlı hareket etmek, nakledilen haberleri kavrayabilecek ince bir anlayışa sahip olmak, hadislerdeki illetleri ve kapalı hususları farkedebilmek, heva ve hevese uymamak, hissî davranmamak, öfkeyle hareket etmemek, aceleci ve ön yargılı olmamak.

Tartışmada, eleştiride ve fikir teatisinde asıl gaye, gerçeği ortaya koymak ve hakikati bulmak olmalıdır. ${ }^{30} \mathrm{Bu}$ gayeye ulaşabilmek için de hadisi veya râvîleri sorgulayan kişinin öncelikle kendi otokritiğini yapması gerekmektedir. Hatta günümüz araştırmacılarının da bu hususa dikkat etmeleri zorunludur. Aksi durumda yapılan değerlendirmeler subjektiflikten uzak olamaz.

Peki râvî tenkidinde yüzde yüz objektiflikten bahsetmek mümkün müdür? Bu sorunun yanıtı için "ravî tenkidinde objektiflik"ten kastedilenin tam olarak ne olduğunun cevabını vermek gerekmektedir. Hadis ilmi de tarih ilmi gibi nakle dayalı bir ilim ${ }^{31}$ olduğundan metodoloji açısından da bazı benzerlikleri vardır. Râvî tenkidindeki objektiflik de tarih ilmindeki objektiflik gibi değerlendirilebilir.

“(...) Her tarihçinin yapıtında öznel ögeler vardır ve içinde bulunduğu zamanın ve yerin etkilerini taşır. Saltık ve zamandan bağımsız nesnellik, gerçek-dışı bir soyutlamadır. Ama tarih, geçmişin olaylarının tarihçinin benimsediği bir nesnellik ilke ve ölçüsüne göre seçilip düzenlenmesini gerektirir; bu iş zorunlu olarak yorum ögelerini de içerir. Bu olmazsa geçmiş, önemsiz ve birbirinden kopuk sayısız ayrıntılara dönüşür ve tarih yazmağa olanak kalmaz." 32

matematiksel bir objektiflik tarih ilminde mümkün olmadığı gibi hadis ilminde de imkansızdır. ${ }^{33}$ Tabiî bilimler de dahil olmak üzere insanın müdâhil olduğu hiçbir araştırma subjektiflikten tamamıla arınmış değildir. ${ }^{34}$ Başka bir ifadeyle; "mutlak adalet" Allah'a ait olduğu gibi "mutlak objektiflik" de sadece O'na aittir. ${ }^{35} \mathrm{Bu}$ açıdan da denilebilir ki; râvî tenkidinde mutlak objektiflik yerine insân̂ि objektiflik ${ }^{36}$ mevcuttur. Hadis tarihine bakıldığında elbette ki subjektif örneklerin olduğu inkar edilemez. Fakat burada önemli olan husus bu sübjektivitenin cerh- ta'dîl ilmine olan güveni yok sayacak seviyede baskın olmadığı, söz konusu subjektif örneklerin hususi olarak değerlendirilmesi gerektiği ve asla umumileştirilemeyeceğidir. Aksini savunmamız durumunda bütün bir hadis birikimini yok saymamız ve hadisleri kaynak olma konumundan çıkarmamız gerekmektedir ki bunun da, dayanakları sıhhatli olmayan radikal bir iddia olduğu anlaşılmaktadır.

\section{RÂVÎ TENKİDİNDE OBJEKTİFLİĞE ENGEL TEŞKİL EDEN DURUMLAR}

\footnotetext{
29 İbnu's-Salah, Mukaddime, 390.

${ }^{30}$ Şakir Gözütok, "İslâm Âlimlerinin Bağımsız Düşünme Ve Eleştiri Anlayışı -Emevî ve Abbasîler Dönemi-", Turkish Academic Research Review - Türk Akademik Araştırmalar Dergisi [TARR] 5/2 (Haziran 2020), 190.

${ }^{31}$ Aba, "Duygusal Yakınlık Bağlamında Nesnel Cerh Uygulama Örnekleri (Baba-Oğul/Hoca-Talebe Özelinde)", 126.

32 E. H. Carr; J. Fontana, Tarih Yazımında Nesnellik ve Yanlılk, çev. Özer Ozankaya (Ankara: İmge Kitabevi, 1992), 14.

${ }^{33}$ Fatma Acun, "Tarihte Objektiflik Tartışması", Muhafazakar Düşünce Dergisi 7/2 (2006), 109.

${ }^{34}$ Acun, "Tarihte Objektiflik Tartışması", 114.

35 Şefaettin Severcan, "Hz. Peygamber ve Dört Halife Dönemi", “Rivayetlerin Bilimselliği", ÍSTEM 5/9 (2007), 27.

36 Acun, “Tarihte Objektiflik Tartışması", 109.
} 
İnsan, fitrat itibarıla hata yapabilen bir varlıktır. Muhaddislerin biyografilerini incelerken de bu realiteyi göz önünde bulundurarak hataların kaynaklarını, sebeplerini tespit etmek gerekmektedir. Yapılan araştırmalarda objektifliğe engel olan birçok farklı durumun olduğu tespit edilmiştir. Söz konusu bütün durumları ayrıntısıyla ele alıp incelemek araştırmanın hacmini aşacağından konuyla doğrudan ilgili olan bazı hususları burada ele alacağız.

\section{1. Şahsî Anlaşmazlıkların Etkisi}

Muhaddisler insanî bir durum olarak zaman zaman şahsî anlaşmazlıkların etkisinde kalabilmişlerdir. Bunlar kişisel problemler sonucu oluşan kırgınlık, haset, öfke, düşmanlık vs. sebeplerle ortaya çıkmış olabilir. Buna binaen muhaddislerin birbirlerine yönelttikleri tenkitler ele alınırken bu durumun da ihmal edilmemesi ve bu doğrultuda hareket edilmesi gerekmektedir. Bilhassa akran olanların birbirlerini cerh ettikleri meseleler değerlendirmeye tabi tutulduğunda teenni ile hareket edilerek kapsamlı bir değerlendirme yapılmalı ${ }^{37}$, sebepleri net bir şekilde açıklanmayan cerhler kabul edilmemelidir. ${ }^{38}$ Kaynaklara bakıldığında meşhur muhaddislerden de bu hataya düşenlerin olduğu görülür. Mesela İmam Mâlik (öl. 179/795), İbn İshak (öl. 151/768) hakkında "Deccâllerden bir deccâldir." demiştir. ${ }^{39}$ Buna mukabil Abdullah b. Nâfî” (öl. 206/822) den gelen rivayette İbn İshak' ın “İmam Mâlik' in bazı kitaplarını getirin de kusurlarını açıklayayım, ben onun kitaplarının baytarıyım." 40 dediği nakledilir. Bu durumdan anlaşıldığı kadarıyla İmam Mâlik de ilmini küçümsemesi¹ sebebiyle İbn İshak' 1 ağır bir dille tenkit etmiştir.

Öte yandan Ahmed b. Sâlih (öl. 248/862) adaletine şahitlik yapacak iki kişiyle gelmeyene hadis rivayet etmemiştir. Nitekim Nesâî (öl. 303/915) de ondan hadis dinlemek üzere izinsiz bir şekilde meclisine girince Ahmed b. Sâlih daha önce onu hiç görmediği için tanımamış ve dışarı çıkarılmasını istemiştir. ${ }^{42}$ Ahmed b. Sâlih'in Nesâî́ye bu şekilde sert davranması ve meclisinden kovması aralarındaki ilişkiyi bozmuş ${ }^{43}$ ve Nesâî bu yüzden onu cerhetmiştir. ${ }^{44}$ Ancak bu cerh, aralarındaki kırgınlık sebebiyle meydana geldiği için mûteber görülmemiştir.45 Nitekim Ahmed b. Sâlih'ten

${ }^{37}$ Ebû Abdillâh Şemsüddîn Muhammed b. Ahmed b. Osmân ez-Zehebî, Mîzânü'l-i 'tidâl fî̀ nakdi'r-ricâl, thk. Ali Muhammed el-Becâvî (Beyrût - Lübnân: Dârü'l-Mârife, 1382/1963), 3/81.

38 Ebu'l-Hasenât Muhammed Abdülhay b. Muhammed Abdilhalîm b. Muhammed Emînillâh es-Sihâlevî elLeknevî, er-Ref've't-tekmîl fi'l-cerh ve't-ta'dîl, thk. Abdulfettah Ebû Gudde (Halep: Mektebetü'l-Matbûati'lİslâmiyye, 1407), 425.

${ }^{39}$ Ebû Yûsuf Ya'kūb b. Süfyân b. Cüvvân el-Fesevî, el-Ma'rife ve't-târîh, thk. Ekrem Ziyâ el-Ömerî (Beyrût: Müessesetü'r-Risâle, 1401/1981), 3/32; Ebû Ahmed Abdullāh b. Adî b. Abdillâh el-Cürcânî, el-Kâmil fi du'afâ'i'r-ricâl, thk. 'Adil Ahmed Abdulmevcûd - Ali Muhammed Muavvız (Beyrût-Lübnân: el-Kütübü'l'İlmiyye, 1418/1997), 7/255.

40 Ebû Abdullah Muhammed b. Ahmed b. Osman b. Kaymaz ez-Zehebî, Siyeru a'lâmi'n-nübelâ, thk. Şu'ayb elArnaût (Beyrût: Müessesetü'r-Risâle, 1985), 7/39.

${ }^{41}$ Ebû Muhammed Abdurrahmân b. Muhammed b. İdrîs er-Râzî İbn Ebû Hâtim, el-Cerh ve't-ta'dîl (Beyrût: Dârü İhyâi't-Türâsi'l-Arabî, 1952), 7/193; Zehebî, Mîzân, 3/469.

42 Zehebî, Siyer, 9/522.

${ }^{43}$ Ebû Bekr Ahmed b. Alî b. Sâbit el-Bağdâdî, Târîhu Bağdâd, thk. Beşşâr Avvâd Ma'rûf (Beyrût: Dâru'l-Garbi'lİslâmî, 1422/2002), 5/319.

${ }^{44}$ Ebû Abdirrahmân Ahmed b. Şuayb b. Alî en-Nesâî, ed-Du 'afâ' ve'l-metrûkîn, thk. Mahmûd İbrâhim Zâyed (Halep: Dârü'l-Vâ̂̂, 1396), 22; Ebû Amr Takıyyüddîn Osmân b. Salâhiddîn Abdirrahmân b. Mûsâ eş-Şehrezûrî , Ulûmü'l-hadîs, thk. Nûreddîn Itr (Beyrût: Dârü'l-Fikr, 1406/1986), 390 Zehebî, Mîzân, 1/103-104,; Zehebi, Siyer, $9 / 522$.

${ }^{45}$ Kemal Sandıkçı, “Ahmed b. Sâlih et-Taberî”, Türkiye Diyanet Vakfı İslâm Ansiklopedisi (Erişim 20 Haziran 2021). 
77 Veli Aba - Nuray Korkmaz / Râvî Tenkidinde Objektiflik Üzerine Bir Değerlendirme / An Evaluation of Objectivity in Rāwī's Criticism

rivayette bulunan İmam Buhârî (öl. 256/870) onu sika saymıştır ve hakkında yapılan konuşmaların da delilsiz olduğunu ifade etmiştir. ${ }^{46}$ İbn Hibbân (öl. 354/965) da Ahmed b. Sâlih'e es-Sikât'ında yer vermiştir. ${ }^{47}$

Ahmed b. Hanbel'in (öl. 241/855), İbrahim el-Harbî́nin (öl. 285/899) ve Ebû Zur'a erRâzî́nin (öl. 264/878) önceleri direndiği halde sonradan canını kurtarmak için Kur'an'ın mahluk olduğunu söyleyen Ali b. el-Medînî’den (öl. 234/848-49) rivayeti terk etmelerini48 de şahsî kırgınlık sebebiyle hissî davranma bağlamında değerlendirebiliriz.

Gerek İmam Mâlik, gerek Nesâî ve Ahmed b. Hanbel gibi büyük imamların bu şekildeki tenkidleri de şahsî olarak değerlendirilmeli ve insan olmalarının bir neticesi şeklinde yorumlanmalı; bu durumun onların hadis ilminde gösterdikleri gayretlere gölge düşürücü mahiyette olmadığ1 belirtilmelidir. Ayrıca tespit edilen bu sebepler dışında da farklı sebeplerin olabileceği ihtimali göz önünde bulundurularak hüsn-ü zan ile hareket edilmelidir.

Şahsî anlaşmazlıklar neticesinde birbirini cerheden şahısların önceki hâlleri göz önünde bulundurularak bir kanaate ulaşmak elbette ki objektiflik bakımından yerinde bir yöntemdir. Önemli olan husus, cerhle ilgili sarfedilen sözlere şahsi anlaşmazlıkların ne derece etki ettiğidir. Söz konusu anlaşmazlıklara rağmen cârihin tarafsızlığını muhafaza edebileceği ihtimali de göz önünde bulundurulmalıdır. Dolayısıyla cârihin şahsî anlaşmazlık halinde bulunduğu kişiye yönelik tenkidinin tamamının yegane sebebi olarak bu durumun gösterilerek söz konusu cerhin sübjektif olduğu sonucuna ulaşmak hatalı bir yaklaşımdır. Bilakis bu yaklaşımın kendisi sübjektif olmuş olur.

\subsection{Mezhep Taassubu ve İtikâdî Muhalefet 49}

İnsan itikâdî, amelî, hukûkî, sosyal, siyasal, ekonomik, kültürel vs. olmak üzere pek çok açıdan yaşadığı toplumun bir parçası olduğundan o toplumda carî maddî manevî değerlerden etkilenmiştir. Bir mezhebe bağlı olma durumu da bu değerlerdendir. ${ }^{50}$

Mezhepler esas itibarıyla temel kabulleri, ilkeleri ve yöntemi olan duruş yerleri olduğundan bir görüşü/mezhebi isabetli ve üstün bulup ona bağlanmak, onu savunmak hatalı bir tutum değildir. Yanlış olan, hakikat başka yerde olsa dahi israrla ona teslim olmamak ve mensup olunan mezhebi taassup ile taklit etmektir. Hakikatçilik, yani sahip olunan mezhebin hakikati temsil ettiğini düşünmek doğal karşılanırken tek hakikatin bu olduğunu, bunun dişındakilerin kesinlikle hatalı ve batıl olduğunu öne sürmek ise son derece yanlış telakki edilmektedir. ${ }^{11}$ Şahısların, mensubu oldukları düşünce sistemine taassupla bağlanmaları, olaylara dar bir çerçeveden bakmalarına ve kendileri gibi düşünmeyenlere bazı haksız tenkitlerde bulunmalarına sebebiyet vermektedir. ${ }^{52}$ Mamafih tenkitler değerlendirilmeye tabi tutulduğunda cerhedenlerin, tezkiye edenlerin ve

${ }^{46}$ Zehebî, Mîzân, 1/104.

${ }^{47}$ Zehebî, Siyer, 12/168.

${ }^{48}$ Zehebî, Mîzân, 3/138.

49 İbn Dakîkul'îd, el-i̇ktirâh, 58.

${ }^{50}$ Hüseyin Kahraman, "Hadis Şerhinde Mezhep Faktörü", Usul İslam Araştırmaları Dergisi 7/7 (2007), 7.

${ }^{51}$ H. Yunus Apaydın, "Bir Savunma Refleksi Olarak Eleştiri ve Tartışma", İslâm Düşüncesinde Eleştiri Kültürü ve Tahammül Ahlâkl, ed. Masum Aytepe - Teceli Karasu (İstanbul: Ensar Neşriyat, 2019), 35.

52 Gözütok, “İslâm Âlimlerinin Bağımsız Düşünme Ve Eleştiri Anlayışı -Emevî ve Abbasîler Dönemi-”, 178. 
hakkında konuşulan kişilerin mezhepleri incelenmeli, farklı olduğu görüldüğünde şüpheleri giderecek açıklama yapılana kadar tevakkuf edilmeli, müfesser olmadığı sürece cerh kabul edilmemelidir.53 Örnek vermek gerekirse Yahyâ b. Maîn'in (öl. 233/848) İmam Şâfiî (ö. 204/820) hakkında "sika değil" demesi onun taassup derecesinde bir Hanefî olması sebebine dayandırılmaktadır ${ }^{54}$ ve bu cerh makbul sayılmamaktadır.

Hadis ekolü önderi kabul edilen Ahmed b. Hanbel "Ehl-i re'y'den hadis rivâyet edilemez." 55 diyerek ehl-i reyi net bir şekilde cerh etmiştir. Aynı şekilde İshak b. Nuceyh el-Maltî́yi de "insanların en yalancısı" ifadesiyle cerh etmiş ve bu yalancılığının sebebini Ebû Hanîfe' den yaptı̆̆ rivâyetlere dayandırmıştır. ${ }^{56}$ Fakat burada belirtmekte fayda vardır ki Ahmed b. Hanbel bizzat kendisi de bu konudaki zafiyetlerini itiraf sadedinde şöyle bir açıklama yapmıştır: "Şafiî gelene kadar biz (hadis ehli) rey ehline, onlar da bize lanet ediyordu. Şafiî aramızı birleştirdi." ${ }^{57} \mathrm{Bu}$ açıklama aynı zamanda bir otokritiktir ve objektif bakış açısının yansımasıdır. Dolayısıyla önceden icra edilen mutaassıp değerlendirmelerin geçersizliğinin de işaretidir.

Dikkatlere sunulması gereken diğer bir husus da mensûbiyet hissinin duygusal ve ilmî yönlerini tefrik etmenin meşakkatli bir iş olduğudur. Şâyet "ilmîlik", elde edilen neticelerin gerekçelerinin ve dayandığı temel prensiplerin okuyucuya hatırlatılıp kendi içinde çelişmeden makul bir bütünlük oluşturan çözüm tarzı ise, ${ }^{58}$ bu tavrı takınarak tenkit eden münekkidin mezhep taassubu içerisine girdiğini iddia etmek de isabetli olmamaktadır.

\section{3. Ön Yarg1 ile Hareket}

Ön yargı; Bir kimse veya bir şeyle ilgili olarak belirli şart, olay ve görüntülere dayanarak önceden edinilmiş olumlu veya olumsuz fikir, peşin yarg1, peşin hüküm ${ }^{59}$ demektir. Tanımda, sahip olunan yargının "olumlu veya olumsuz" olarak ele alınması câlib-i dikkattir. Bu durumda kavram zannedilenin aksine tüm ön yargıların menfî olmayacağı anlamına gelmektedir. Bu açıdan bakıldığında önceden sahip olunan yargıların doğrulanması durumunda ön yargı müspet bir anlam üstlenmektedir. Diğer taraftan hâkîkate ulaşmaya set oluşturacak bir ön yargı ise menfi olmaktadır. Dolayısıyla menfî anlamda ön yargı objektifliğge engel teşkil etmektedir.

Evzâî́nin (öl. 157/774) İmam-1 Âzam Ebû Hanîfe'yi (öl. 150/767) tenkid etmesi onu yeterince tanımadığı hususuyla izah edilmiştir. İbn Manzûr'un (öl. 711/1311) verdiği bilgiye göre Abdullah

\footnotetext{
53 İbn Dakîkul'îd, el-ìktirâh, 59.

${ }^{54}$ Ebû Abdillâh Şemsüddîn Muhammed b. Ahmed b. Osmân ez-Zehebî, er-Ruvâtü's-sikât el-mütekellem fihim bimâ lâ yûcibü reddehüm, thk. Muhammed İbrâhim el-Mevsllî (Beyrût-Lübnân: Daru'l-Beşâiri'l-İslâmiyye, 1412/1992), 29-30.

55 Ebû Abdillâh Ahmed b. Muhammed b. Hanbel eş-Şeybânî el-Mervezî, el-'illel ve ma 'rifetü'r-ricâl, thk. Vasiyyullah b. Muhammed Abbâs (Riyad: Dârü'l-Hâni, 1422/2001), 2/102.

${ }^{56}$ Ahmed b. Hanbel, el- '́llel, 2/30; Ehl-i hadis ve ehl-i rey arasındaki polemiklerin cerh-tadile etkisi hakkında detaylı bilgi için bk. Uğur Erman, “Ehl-i Hadîs ve Ehl-i Re'y Arasinda Yaşanan Polemiklerin Cerh ve Ta'dîl İlmine, Dönemin Te'lîfâtina ve Sosyal/Beşerî İlişkilere Yansimasi (Hicrî III. Asir)", e-Şarkiyat İlmi Araştırmaları Dergisi/Journal of Oriental Scientific Research (JOSR) 9/2 (2017).

${ }^{57}$ Ebü'l-Fazl İyâz b. Mûsâ b. İyâz el-Yahsubî, Tertîbü'l-medârik ve takrîbü'l-mesâlik, thk. Muhammed b. Tâvît etTancî vd. (Mağrib: Matbaatü Fedâle el-Muhammediyye, 1965, 1966, 1970, 1981, 1983 ), 91.

${ }^{58}$ Kahraman, "Mezhep Faktörü", 19.

59 Parlatır vd., "ön yargı" 2/1734.
} 
b. Mübârek, Evzâî́nin Beyrût'ta yaşadı̆̆ı köyüne geldiğinde kendisine "Ey Horasanlı, Kufe'den çıkan kişi yani Ebû Hanîfe kimdir?" diye sorduğunu ve bunun üzerine eve döndüğünü Ebû Hanîfe'nin kitaplarına ulaşarak mükemmel konuları özetleyip elde ettiğini bu şekilde üç gün kaldığını söyler. Üçüncü gün onları getirdiğini ve bu sırada Evzâî́nin müezzinlik ve imamlık yaptığını bildirir. Evzâî ona elindekinin hangi kitap olduğunu sorar. Bunun üzerine İbn Mübârek kitabı ona verir. Kitaptaki konulardan birinde "Nu'man b. Sâbit dedi ki" ifadesine rastlar. Ezan okuduktan sonra henüz ayakta iken bir müddet kitaptan okur. Sonra kitabı giysisinin koluna koyar, namaz kıldıktan sonra çıkarır ve bitirir. Daha sonra İbn Mübarek'e "Ey Horasanlı bu Nu'man b. Sabit kimdir?" diye sorar. İbn Mübârek "Irak'ta karşılaştığım bir şeyhtir." diye cevap verir. Bunun üzerine Evzâî: "Bu muazzam şeyhlerdendir, git ve ondan daha fazla istifade et." der. Bunun üzerine Abdullah b. Mübârek: "Bu, beni kendisinden nehyettiğin Ebû Hanîfe'dir." der.60 Buradan da anlaşılıyor ki aslında Evzâî İmam Azam Ebû Hanîfe' yi tanımadığı için haksız tenkitte bulunmuştur. Bu tanımanın önündeki engel Ebû Hanife'nin Iraklı bir âlim olması ve Evzâînnin Iraklılara karşı ön yargilı olmasıdır. Zira Evzâî'nin İmam Muhammed'e yönelik tenkidi de bununla benzerlik taşımaktadır. es-Siyerü's-sağîr adındaki eser Evzâî́ ye ulaştığında onun kimin eseri olduğunu sormuş ve İmam Muhammed'e ait olduğunu öğrenince "Iraklılar nerde, bu konuda kitap tasnif etmek nerde."61 diyerek onların Siyer ilmi hakkındaki konumlarını küçümsemiştir. Evzâî́nin bu konuşması İmam Muhammed'e ulaşınca onu öfkelendirir ve dehşete düşürür. Bunun üzerine esSiyerü'l-kebîr'i tasnif eder. Evzâî bu kitabı incelediğinde “Onun içerisine hadisleri dahil etmemiş olsaydı ilmi kendinden uydurdu derdim. Allah cevabın doğruluğunu onun düşüncesinde tayin etti." diyerek "Her ilim sahibinin üstünde daha iyi bir bilen vardır."62 şeklindeki Yusuf sûresi 76. ayeti okur. ${ }^{63}$ Burada da görülüyor ki Evzâî́nin başlangıç itibarıyla sahip olduğu ön yargı onu haksız tenkide sevketmekte iken sonrasında hatasını anlayarak düzeltmesi, ilmî duruş sergilemesini netice vermiştir.

\subsection{Hadis İlminde İhtisas Sahibi Olmama}

Râvîler hakkında doğru hüküm verebilmek için hadis, ilel ve ricâl ilimlerinde mütehassıs olunmalıdır. Tâceddin es-Sübkî” nin (ö. 771/1370) “Umûmiyetle, cerh edenin bir lafzı işittiğini ancak yanlış bir şekilde kavradığını görmüşümdür. Elfâzın içeriği ile alakalı teknik bilgi ve bilhassa insanların örfüne göre farklılıklar içeren ve kimi zaman takdir kimi zaman tekdir anlamı veren lafızlar gerçekten alanında uzman olan kişi dışındaki için zor bir meseledir." 64 şeklindeki açıklamalarında da görüldüğü üzere cerh-ta' dîl lâfızlarının ne ifade ettiğinin de çok iyi bilinmesi ve bu lâfızlardan büyük imamların kendilerine has ıstılahlarının tespit edilmesi büyük bir ehemmiyet

${ }^{60}$ Ebü'l-Fazl Cemâlüddîn Muhammed b. Mükerrem b. Alî b. Ahmed el-Ensârî er-Rüveyfiî, Muhtasaru Târîhi Dımaşk, nşr. Rûhiyye en-Nehhâs vd. (Dımaşk - Suriye: Dâru'l-Fikr, 1402/1984), 14/14.

${ }^{61}$ Ebû Bekr Şemsü'l-eimme Muhammed b. Ebî Sehl Ahmed es-Serahsî, Şerhu's-Siyeri'l-kebîr (b.y.: Şirketu'şŞarkıyyetu'l-İlânât, 1971), 3; İsmail Hakkı Ünal, İmam Ebu Hanife'nin Hadis Anlayışı ve Hanefi Mezhebinin Hadis Metodu (Ankara: Diyanet İşleri Başkanlıḡı, 2012), 272.

62 el-Furkan 25/76.

${ }^{6}$ Ünal, İmam Ebu Hanife'nin Hadis Anlayışı ve Hanefi Mezhebinin Hadis Metodu, 3.

${ }^{64}$ Ebû Nasr Tâcüddîn Abdülvehhâb b. Alî b. Abdilkâfî es-Sübkî, Tabakâtü'ş-Şâfiiyyeti'l-kübrâ, thk. Mahmûd Muhammed et-Tanâhî - Abdülfettâh Muhammed el-Hulv (Kahire: Dâru Hicr, 1413), 2/18. 
arz etmektedir. ${ }^{65}$ Aksi takdirde cerhedilen kişiler âdil, ta' dîl edilen kişiler, mecrûh; sahih olan hadis, zayıf; zayıf olan hadis, sahih olarak anlaşılıp yanlış değerlendirilir. ${ }^{66}$

Örnek vermek gerekirse münker hadis ${ }^{67}$, çoğu muhaddise göre, zayıf râvînin sika râvîlere muhalefet ederek rivâyet ettiği hadistir ve merdûddur. ${ }^{68}$ Ahmed b. Hanbel ve Berdîcî gibi bazı muhaddisler ise münker hadisi, sika bir râvînin tek başına rivâyet ettiği hadis olarak tanımlamışlardır. Birinci tarife göre, münker hadis rivâyet eden râvî mecrûh olurken; ikinci tanıma göre, münker hadis rivâyet etmek cerhe sebep teşkil etmemektedir. Mesela Ahmed b. Hanbel, Muhammed b. İbrâhîm et-Teymî hakkında "Münker hadisler rivâyet eder" demektedir. Ukaylî, Ahmed b. Hanbel'in bu sözünü birinci tarifteki münker olarak değerlendirip et-Teymî́yi mecrûh saymıştır. ${ }^{69}$

\subsection{Yakınlık Bağının Bulunması}

İnsanı muhatap alan bütün ilimlerde gözden kaçırılmaması gereken önemli bir husus da insanın duygusal yönünün ihmal edilmeden ele alınması gerektiğidir. Bu açıdan münekkitlerin de zaman zaman bu duygusallığın tesirinde kaldıkları görülmüştür. Aralarında sıhriyyet, hoca-talebe ilişkisi, düşünce, ırk veya coğrafya birlikteliği gibi yakınlıkların olması tarafgir davranmalarına sebebiyet verebilmiştir. Bazen de mensubiyet farklılığı ravileri şiddetli eleştiri oklarına maruz bırakabilmiştir. Dolayısıyla her iki durumda da subjektiflik ön plana çıkmaktadır.

Hatîb el-Bağdâdî' den (ö. 463/1071) sonra "ikinci Hatîb" diye meşhur olan70 İbn Mâkûlâ (ö. 475/1082' den sonra) Hatîb el-Bağdâdî́nin el-Mü'tenif fì tekmileti'l-muhtelif ve'l-mü'telif adlı eserini tenkit etmek üzere Tehzîbü müstemirri'l-evhâm adlı eserini kaleme almıştır. Böyle bir eser yazdığ1 bilgisi Hatîb el-Bağdâdî̀ye ulaşınca İbn Mâkûlâ hocasına böyle bir çalışmasının olmadığını söylemiş, hocasının vefatının akabinde yapmış olduğu bu çalışmayı ortaya çıkarmıştır. ${ }^{11}$ İbn Makula'nın başlangıçta sergilemiş olduğu tavır hoca-talebe ilişkisinden kaynaklı duygusal yakınlığın tesirinde kaldığının göstergesidir. Daha sonra ise ilmî davranarak söz konusu tenkitlerini ilim ehlinin istifadesine sunması onun bu duygusal yakınlığın olumsuz etkisinden kurtulduğuna delalet etmektedir.

\subsection{Sosyal ve Siyasî Baskı}

İnsan tek başına yaşayabilen bir varlık değildir. Bilakis toplumla varlığını idame ettirebilen bir varlıktır. Bu bakımdan da içinde bulunduğu toplumun bir ürünü ve aynasıdır. Cerh-ta dîl âlimleri

${ }^{65}$ Ebû Abdillâh Şemsüddîn Muhammed b. Ahmed b. Osmân ez-Zehebî, el-Mûkıza "fí 'ilmi mustalahi'l-hadîs", thk. Abdulfettah Ebû Gudde (Halep: Mektebetü'l-Matbûati'l-İslâmiyye, 1412), 82.

66 Örnekler için bk. Polat, Hadis Araştırmaları, 63-65.

${ }^{67}$ Münker hadisle ilgili daha fazla bilgi için bk. Mehmet Efendioğlu, "Münker", Türkiye Diyanet Vakfı Ansiklopedisi (Erişim 30 Ağustos 2021).

${ }^{68}$ Ebu'l-Fadl Ahmed b. Ali b. Muhammed b. Ahmed b. Hacer el-Askalâni, Nüzhetü'n-nazar fì tavzîhi Nuhbeti'lfiker fi mustalahi ehli'l-eser, thk. Abdullah b. Dayfullah er- Râhilî (Riyad: Matbaatü Sefîr, 1422), 112.

${ }^{69}$ Ebû Ca'fer Muhammed b. Amr b. Mûsâ el-Ukaylî, ed-Du 'afâ' 'ü'l-kebîr, thk. Abdülmu'tî Emîn Kal'acî (Beyrût: Dârü'l-Mektebeti'l-İlmiyye, 1404/1984), 4/20; Ayrıca bk. Polat, Hadis Araştırmaları, 64-65.

${ }^{70}$ Nuri Topaloğlu, "İbn Mâkûlâ", Türkiye Diyanet Vakfi İslâm Ansiklopedisi (Erişim 22 Mart 2021).

${ }^{71}$ Ebû Abdillâh Şemsüddîn Muhammed b. Ahmed b. Osmân ez-Zehebî, Tezkiretüll-huffâz (Beyrût - Lübnân: Dârü'l-Kütübü'l-İlmiyye, 1419/1998), 4/4. 
81 Veli Aba - Nuray Korkmaz / Râvî Tenkidinde Objektiflik Üzerine Bir Değerlendirme / An Evaluation of Objectivity in Rāwī's Criticism

de râvîler hakkında hüküm verirken zaman zaman içinde bulundukları sosyal ve siyasî baskıdan etkilenebilmişlerdir. Bu nedenle söz konusu değerlendirmeler irdelenirken olayın vuku bulduğu ortamın şartlarını göz önünde bulundurmak, daha doğru sonuçlar elde etmeyi sağlayacaktır.

Hicri II. asrın sonları ile III. asrın başları İslâm tarihinde sistemli tedvin faaliyetinin ortaya çıkmaya başladığı zaman dilimidir. Bu asırlar aynı zamanda Şîa ve Haricîler başta olmak üzere birçok itikadî ve siyasî fırkanın fikirlerinin de zuhur ettiği devrelerdir. Ortaya çıkan bu fırkalar mevcut idareler ile muhalefet ve mücadele içerisinde olmuşlar ve tarihî olaylar ve şahsiyetleri tarafgir bir bakış açısıyla tanıtmışlardır. Şia'nın, Haricîlerin ve diğer fırkalara mensup râvî ve tarihçilerin yazdıkları eserler de bu minvalde vücut bulmuştur. ${ }^{72}$ Meselâ Taberî'nin kendisinden sık sık rivayet aldığı râvîlerden birisi olan Ebû Mihnef Lût b. Yahya bir Şiîdir. ${ }^{73}$

Buhârî el-Câmiu's-Sahîh adlı eserinde Câfer es-Sâdık'tan rivayette bulunmamıştır. Bu durum onun Nâsıbî ${ }^{74}$ olduğuna ve ehl-i beyte karşı mesafeli olduğuna gerekçe değildir. Çünkü onun her sikadan rivayet edeceğine dair bir şartı bulunmamaktadır. ${ }^{75}$ Aynı şekilde Buhârî́nin bu tutumu Câfer es-Sâdık'a güvenmediği veya sika kabul etmediği anlamına da gelmez. Çünkü Buhârî Târîhu'lkebîr adlı eserinde Ca'fer es-Sâdık'a yer vermiş76 ve zayıf ravilere yer verdiği Kitâbu'd-duafâu'ssăğ $r^{\prime}$ 'inde ise Cafer es-Sadık'ı zikretmemiştir. Cafer es-Sadık'ın talebesi İmam Mâlik de Abbasiler dönemine kadar ondan rivayette bulunmamıştır. ${ }^{77}$ İmam Buhari ve İmam Malik' in bu tavırlarının altında yatan en önemli sebep dönemin siyasî olaylarıdır denilebilir.

İmam Buhârî Ashabu'n-Nebi (62) bölümünde pek çok sahâbî için "bâbü menâkıbi..."78 "babü fadli/fedâili..."79 şeklinde bab başlığı kullanmıştır. Muaviye b. Ebî Süfyân ile alâkalı bâbı "bâbu zikri Muaviye"(Muaviye' nin anılması babı) ${ }^{80}$ şeklinde adlandırmıştır. Bu uygulaması siyâsî baskı ihtimalini düşündürse de bu yaklaşım isabetli gözükmemektedir. ${ }^{81}$ Çünkü aynı kitapta Abbas b.

72 Ahmet Önkal, “İslam Tarihçiliğinde Tarafsızlık Problemi”, Marife Dergisi 5/1 (2005), 253.

${ }^{73}$ Zehebî, Mîzân, 3/419-420.

74 İmâmiyye Şîası literatüründe Hz. Ali'ye, evlâtlarına ve taraftarlarına karşı olan zümrelere verilen bir isimdir. (Öz, 9 Kasım 2021). Nâsıbî kavramı hakkında daha detaylı bilgi için ayrıca bk. Hilmi Kemal Altun, "Nâsıbî Kavramı Üzerine Tahlil ve Değerlendirme", Pamukkale Üniversitesi İlahiyat Fakültesi Dergisi, 7/2 (Aralık 2020).

${ }^{75}$ Enbiya Yıldırım, Hadis İlminin İncelikleri (İstanbul: Ensar Neşriyat, 2021), 135-136.

${ }^{76}$ Ebû Abdillâh Muhammed b. İsmâîl b. İbrâhîm el-Cu'fî el-Buhârî, et-Târîhu'l-kebîr, thk. Muhammed Abdü'lMuîd Han (Haydarâbâd: Dârü'l-Maârifi'l-Osmâniyye, ts.), 2/198; Cafer es-Sadık'ın Hadisçiliği ile ilgili daha fazla bilgi için bk. Abdulkadir Evgin, "Sünni Kaynaklara Göre Cafer es-Sâdık'ın Hadisciliği”, Dini Araştırmalar 12/35 (2009).

77 Ebû Ahmed Abdullāh b. Adî b. Abdillâh el-Cürcânî, el-Kâmil, 2/357; Ebü'1-Haccâc Cemâlüddîn Yûsuf b. Abdirrahmân b. Yûsuf el-Mizzî, Tehzîbü'l-Kemâl fì esmâ'i'r-ricâl, thk. Beşşâr Avvâd Ma'rûf (Beyrût: Müessesetü'r-Risâle, 1400/1980), 5/76.

${ }^{78}$ Ebû Abdillâh Muhammed b. İsmâîl b. İbrâhîm el-Cu'fî el-Buhârî, el-Câmiu's-sahîh, nşr. Muhammed Züheyr b. Nâsir en-Nâsir (Beyrût: Dârü Tavki'n-Necât, 1422/2001), "Ashâbü'n-Nebî", 2, 6, 7, 9, 10-13, 15, 17, 20-24, 27 28,30 .

79 Buhârî, "Ashabü'n-Nebî", 1, 4, 31.

80 Buhârî, "Ashabü'n-Nebî", 29.

81 Yıldırım, Hadis İlminin İncelikleri, 132. 
Abdülmuttalib, 82 Talha b. Ubeydullah, 83 Usâme b. Zeyd, ${ }^{84}$ Ebû'1-Âs b. Rebi', ${ }^{85}$ Abdullah b. Abbas ${ }^{86}$ ile alâkalı babların başlıklarında da "zikr" kelimesini kullanmıştır. Ayrıca Huzeyfe b. Yeman için de farklı kitap ve bablarda hem "menakıb" 87 hem de "zikr" 88 kelimesini kullandığ görülmektedir. Bu da böyle bir farklılığın özel bir mana taşımadığını, bab-içerik alakası dolayısıyla böyle bir tercihte bulunduğu ihtimalini güçlendirmektedir.

Netice itibarıyla bir nevi hâkim konumunda bulunan münekkidden beklenen, herhangi bir râvî hakkında karar verirken mümkün mertebe, ölçülü ve mûtedil olmaya çalışması, gerekli dikkat, titizlik ve hassasiyeti göstermesidir. ${ }^{89}$ Bununla beraber objektifliğe engel teşkil eden mezkur durumların görülmesi hadis ilminin yapısını veya bir hadisin sıhhatini etkilemediği sürece belli oranda normal karşılanmalıdır. Çünkü cerh-tadil sistemi tekil ifadelerden ziyade bütüncül değerlendirmelerden müteşekkildir. Bu bakımdan da nesnel bir gerçekliğe dayandırılmayan, şahsî duyguların etkisiyle yapılan tenkitlere itibar edilmemiştir. ${ }^{90}$

\section{OBJEKTIF TENKITT ÖRNEKLERI}

Cerh-ta' dîl sisteminin işleyişi ve münekkitlerin râvî tenkitleri ele alındığında objektif olmayan değerlendirmelere umûmiyetle itibar edilmediği görülmektedir. Aynı zamanda tenkit sisteminin denetlenebilir olması ve rasyonel bir mekanizmaya sahip olması da objektifliğin hâkim olduğunun işaretidir. Söz konusu objektif tenkit örneklerinin tasnif edilerek ele alınması önemli bir ihtiyaç olup kanaatimizce burada birkaç tanesine yer vermekle çalışmanın maksadı hasıl olacaktır. Şimdi örneklere geçelim:

Ahmed b. Hanbel, Vâkıdî (öl. 207/823) için “yalancı" (كذاب) demiştir. Devamında da hadisleri değiştirdiğini ifade etmiştir. ${ }^{91}$ Bunun yanında Ahmed b. Hanbel'in, her cuma günü yeğeni Hanbel b. İshak'1 Vâkıdî'nin kâtibi İbn Sa'd'a göndererek onun hadislerinden ikişer cüz aldırması, bunları inceledikten sonra iade etmesi ve başka cüzler de getirtmesi92 Vâkıdî́ yi eleştirdiği halde objektif bir şekilde araştırmalarını yapmaya devam ettiğinin göstergesi olarak değerlendirilebilir.

Ali b. el-Medînî: "Basralıları Kaderî, Kûfelileri de Şiî olmaları sebebiyle terk etmiş olsaydım kitaplar harap olurdu."93 ifadesiyle arkaplanında mezhep ayrılığının yer aldığı belde taassubunun önüne geçmeye ve ihmal edilmesi durumunda da yaşanacaklara dikkatleri çekmiştir. Yine kendisine

\footnotetext{
82 Buhârî, "Ashabü'n-Nebî", 11.

83 Buhârî, "Ashabü'n-Nebî̀", 14.

84 Buhârî, "Ashabü'n-Nebî", 16.

85 Buhârî, "Ashabü'n-Nebî", 18.

86 Buhârî, "Ashabü'n-Nebî", 25.

87 Buhârî, "Ashabü'n-Nebî", 21.

88 Buhârî, "Menâkibu'l-Ensar", 22.

89 Abdullah Karahan, "el-Muhallâ Çerçevesinde Değerlendirme", “İbn Hazm’ın Râvi Tenkidinde Eleştirilen Yönlerinin Onun Tenkitçi Kimliğine Etkisi”, Uludă̆ Üniversitesi İlahiyat Fakültesi Dergisi 16/1 (2007), 148.

90 Eymen Kamer, “Akran Râvî Tenkîdinin Değeri”, Hadis Tetkikleri Dergisi 18/2 (2020), 130.

91 Ebû Abdillâh Şemsüddîn Muhammed b. Ahmed b. Osmân ez-Zehebî, Mîzânü'l-i 'tidâl fî nakdi'r-ricâl, $3 / 663$.

92 Mustafa Fayda, "Vâkıdî", Türkiye Diyanet Vakfı İslâm Ansiklopedisi (Erişim 25 Ocak 2021).

93 Hatîb el-Bağdâdî, el-Kifâye, 129.
} 
83 Veli Aba - Nuray Korkmaz / Râvî Tenkidinde Objektiflik Üzerine Bir Değerlendirme / An Evaluation of Objectivity in Rāwī's Criticism

babası hakkında soru soranlara verdiği "Babam zayıftır"94 cevabıyla da sıhriyyete bağlı duygusal yakınlığın objektif değerlendirme yapmasına engel olamadığının güzel bir misalini sergilemiştir.

خربت الكتب Hatîb el-Bağdâdî, İbn Medînî’ye ait bu cümledeki ‘kitaplar harap olurdu' anlamındaki ifadesi ile 'hadis ilmi kaybolurdu' anlamına gelen لذهب الحديث sözcüğünün kastedildiğini ifade eder.95 Salt bu açılama dahi sübjektivitenin ne tür arızalara sebep olabileceğini ortaya koyması açısından dikkat çekicidir.

İbnü'l-Cüneyd el-Huttelî (öl. 270/884 [?]) Sa'îd b. Huseym el-Hilâlî́nin güvenilirliği hakkında Yahyâ b. Ma'în'e sormuştur ve şu cevabı almıştır: "Kûfelidir, onda beis yoktur, sikadır." İbnü'lCüneyd şu bilgileri de ekler: “Bir adam yine aynı şahıs hakkında Yahyâ'ya 'O Şiî midir?' diye sorduğunda o, 'Şî̂ ve sikadır, Kaderî ve sikadır.' dedi." 96 Ahmed b. Hanbel de Müsned' de bu râvînin yer aldığı senetlere yer vermiştir. ${ }^{97}$

Muhammed b. Muhammed el-Bâgendî (öl.312/924) oğlu Ahmed b. Muhammed b. Muhammed b. Süleyman el-Bâgendî (öl. 326/937) (İbn Bâgendî olarak da bilinir.) hakkında “Oğlumdan yazmayın, o yalan uydurur (فانه يكنب)" demiştir. Oğlu da babasını tenkit ederek "Babamdan yazmayın, o 'kezzab'tır (فانه كذاب)"

İbnü'd-Dahîl Yusuf b. Ahmed b. Yûsuf el-Mekkî (ö. 388/998), şeyhi Ukaylî́ye (öl. 322/934) Ebû Hanîfe aleyhindeki cerhinden dolayı reddiye yazmıştır. ${ }^{99}$ Bu hadiseye baktığımızda İbnü'd-Dahîl'in hem hocasına reddiye yazması hem de kendisiyle aynı mezhepten olmayan ${ }^{100}$ Ebû Hanîfe'yi medhetmesi tarafgir davranmadığına ve dikkatleri hakikat namına çaba sarfettiği hususuna çekmektedir.

Abdulganî el-Ezdî (öl. 409/1018) şeklinde de maruf olan hadis ve ensab âlimi Ebû Muhammed Abdulgani İbn Saîd, kendisine getirilen Hâkim en-Nîsâbûrî́nin el-Medhâl ila ma'rifeti's-sahîh adlı eserini alıp incelemiş, onda bazı yanlışlar bulmuştur. Bunun üzerine tespit ettiği hataları bir belgede izah ederek kendisine bildirmiştir. Belgenin eline ulaşması üzerine Hakîm, Abdulganî el Ezdî̀ye güzel bir cevap yazarak teşekkür etmiştir. ${ }^{101}$ Çağdaş olan bu âlimlerin mevzubahis bu tavırları ilmî tenkidin güzel bir numunesidir.

Hatîb el-Bağdâdî, kendisiyle aynı asırda yaşayan İbn Mâkûlâ (öl. 475/ 1082) tarafından eleştiriye tabi tutulmuştur. İbn Mâkûlâ, Hatîb el-Bağdâdî́nin el-Mü' tenif adlı eserini okumuş ve Bağdâdî daha

${ }^{94}$ Ebû Hâtim Muhammed b. Hibbân b. Ahmed el-Büstî, el-Mecrûhîn mine'l-muhaddisîn ve'd-duafâ ve'l-metrûkîn, thk. Mahmûd İbrâhim Zâyed (Halep: Dâru'l-Vâî, 1396), 2/15.

${ }^{95}$ Hatîb el-Bağdâdî, el-Kifâye, 129.

${ }^{96}$ Ebû Zekeriyyâ Yahyâ b. Maîn b. Avn el-Mürrî el-Bağdâdî, Su'âlâtü İbni'l-Cüneyd li Ebî Zekeriyyâ Yahyâab. Maîn, thk. Ahmed Muhammed Nûrseyf (Medîne-i Münevvere: Mektebetü'd-Dâr, 1408/1988), 421.

${ }^{97}$ Ebû Abdillâh Ahmed b. Muhammed b. Hanbel eş-Şeybânî el-Mervezî, el-Müsned, thk. Şu'ayb el-Arnaût - 'Adil Mürşid (b.y.: Mü' essesetü'r-Risâle, 1421/2001), 25/299, 27/278, 279.

${ }^{98}$ Ebü'l-Hasen Ali b. Ömer ed-Dârekutnî, Suâlâtü Hamza'bni Yûsufes-Sehmî li'd-Dârekutnî ve ğayrihî mine'l-meşâyih fi'l-cerh ve't-ta'dîl, thk. Muvaffak b. Abdillah b. Abdilkâdir (Riyad: Mektebetü'l-Me'ârif, 1404/1984), 22.

${ }^{99}$ Zâhid el Kevserî, Te'nîbü'l-Hatîb 'alâ mâ sâkahî fì tercemeti Ebî Hanîfe mine'l-ekâzîb (b.y.: y.y., 1410/1990), 67.

100 Kevserî, Te'nîb, 68.

${ }^{101}$ Ebü'l-Fazl İyâz b. Mûsâ b. İyâz el-Yahsubî, el-İlmâ' ilâ ma 'rifeti usûli'r-rivâye ve takyîdi's-semâ', thk. Seyyid Ahmed Sakr (Kahire-Tunus: Dârü't-Türâs-Mektebetu'l-Atîka, 1379/1970), 229. 
hayatta iken bu kitab üzerine yazdığı Tehzîbu müstemirri'l-evhâm isimli eseriyle onun vehimlerini ortaya koymuştur. ${ }^{102}$

Görüldüğü üzere verilen örnekler râvî tenkidinin genel anlamda objektif bir bakış açısıyla icra edildiğini ortaya koymaktadır. Objektif tenkit örneklerinin yanında daha önce ele alınan sübjektif örneklerin de var olması bu hakikati değiştirmez. Hadisçilerin, râvî ile münekkid arasında mezhep farklılığı var olduğunda cerh sebebinin mezhep taassubuna dayandı̆̆ netleşince cerhe itibar edilmeyeceğini ifade etmeleri,103 akranlar arasındaki dünyevî çekişmelere dayalı cerhin -sebebi açıklansa dahi- kabul edilmemesi, ${ }^{104}$ bid'atının propagandasını yapmayan râvîlerin hadislerinin kabul edilmesi105 ve bu ravilerin tâdil edilmesi gibi hususlar da cerh-ta'dîl sisteminin bizatihî kendisinin bilimsel gerçekliklere dayandığına delil teşkil etmektedir.

\section{SONUÇ}

Objektiflik, tüm bilimlerin en temel unsurlarındandır. Hadis ilminden elde edilen verilerde de bu ilke göz önünde bulundurulmuştur. Fakat burada kastedilen objektiflik mutlak objektiflik değil insanî objektifliktir. İnsanın dahil olduğu hiçbir ilim tam anlamıla subjektiflikten hâli olamaz. Önemli olan bu subjektifliğin kişinin bütün tasarruflarını etkileyip etkilemediği ya da ilgili ilim içerisinde genele yayılacak şekilde ekseriyette olup olmadığıdır. İslâmiyet'in Allah tarafından desteklenip muhafaza edildiğine inanan Müslüman âlimlerin de kasten dalâlet üzere birleşmeleri düşünülemez. Sayılı birtakım subjektif örneklerin olması da bu hakikati değiştirmemektedir.

Hadis âlimleri hak ve hakikat nâmına birbirlerini eleştirmekten geri durmamışlardır. Zaman zaman eleştiride ölçüyü kaçıranlar da olabilmiş fakat genel anlamda bu tenkitler müspet bir seyir almış ve hadis ilminin gelişmesine katkıda bulunmuştur. Tenkit konusunu gündemine alan bir araştırmacıdan beklenen, bilhassa hadis ilminde otorite kabul edilen büyük âlimlerin arasındaki ihtilafları ele almasıdır. Bu ihtilaflar acelecilikten uzak, son derece titiz bir şekilde çok yönlü incelenmeli, sorunun asıl kaynağına ulaşılmaya çalışılmalı ve bağlam dikkate alınarak doğru neticeye ulaşmak için çaba sarf edilmelidir. Bunun aksi bir tutum sergilenmesi kişiyi hataya düşüreceğinden hadis ilmine karşı güveni zedeleyici olur.

Objektiflik genel bir bakış açısıyla ele alınarak râvî tenkidinde objektiflik problemi olup olmadığı araştırıldığında subjektif davranıldığına dair birtakım örnekler tespit edilmiş ve bunların sebepleri bu makalede irdelenmeye çalışılmıştır. Değerlendirmeye alınan subjektif örneklerin birtakım spesifik nedenlere dayandığı ve genele yayılmasının hakkaniyet ve insaf ölçülerine aykırı olduğu; hakim olan anlayış nesnelliğin muhafaza edildiği ve olaylara tarafsız yaklaşıldığıdır.

102 Ebû Abdillâh Şihâbüddîn Yâkūt b. Abdillâh el-Hamevî el-Bağdâdî er-Rûmî, Mu 'cemü'l-üdebâ', İrşâdü'l-erîb ilâ ma 'rifeti'l-edîb, thk. İhsan Abbas (Beyrût: Dâru'l-Garbi'l-İslâmî, 1414/1993), 5/1990; Zehebî, Tezkire, 4/4; Hatîb el-Bağdâdî'ye yöneltilen eleştiriler için ayrıca bk. Veli ABA, Hatîb el-Bağdâdı̂'nin Hadis Usulü Anlayışı (Konya: Necmeddin Erbakan Üniversitesi, Sosyal Bilimler Enstitüsü, Doktora Tezi, 2013), 430-439.

103 Ebû Nasr Tâcüddîn Abdülvehhâb b. Alî b. Abdilkâfî es-Sübkî, Kâide fi'l-cerh ve't-ta'dîl, thk. Abdulfettâh Ebû Gudde (Beyrût: Dâru'l-Beşâir, 1410/1990), 19; Ayrıca bk. A'zam'î, Muhaddislerin Hadis Tenkit Yöntemi, 75.

104 Sübkî, Kâide fi' l-cerh ve't-ta' dîl, 30.

105 A'zam'î, Muhaddislerin Hadis Tenkit Yöntemi, 74. Örnekler için bk. Ebû Abdillâh Muhammed b. Sa'd b. Menî́ el-Kâtib el-Hâşimî el-Basrî el-Bağdâdî, et-Tabakâtü'l-kübrâ, thk. Muhammed Abdülkâdir Atâ (Beyrût: Dârü'lKütübi'l-illmiyye, 1410/1990), 5/45;6/343 , 364;7/169, 232 , 324. 
85 Veli Aba - Nuray Korkmaz / Râvî Tenkidinde Objektiflik Üzerine Bir Değerlendirme / An Evaluation of Objectivity in Rāwī's Criticism

İlgili kaynaklara başvurularak yapılan bu çalışma neticesinde hadis münekkitlerinin râvîleri değerlendirme aşamasında objektif davrandıklarına delil teşkil edecek bir çok örneğin olduğu tespit edilmiştir. Fakat sadece iddiayı delillendirecek miktarda örneklere yer verilerek maksadın hasıl olacağ1 düşünülmüştür. Bu örnekler incelendiğinde münekkitlerin râvîleri değerlendirmeye tabi tuttuklarında kan bağının, hoca-talebe ilişkisinin, şahsî kırgınlıkların, sosyal-siyasal baskı ve korkunun duygusal etkisinde kalmadıkları sürece ekseriyetle objektif tutum sergiledikleri tespit edilmiştir.

Konuyla ilgili yapılacak müstakil çalışmalar objektiflik örneklerinin farklı boyutlarıyla ele alınıp etraflıca değerlendirilerek gün yüzüne çıkarılmasını sağlayacaktır. Bu beklentinin karşılanması cerh-ta'dîl literatürüne ve dolayısıyla hadis ilmine önemli katkı sunacaktır. Bununla beraber interdisipliner açıdan da birçok faydayı beraberinde getirecektir. 


\section{KAYNAKÇA}

Aba, Veli. Hatîb el-Bă̆dâdî'nin Hadis Usulü Anlayışı. Konya: Necmeddin Erbakan Üniversitesi, Sosyal Bilimler Enstitüsü, Doktora Tezi, 2013.

Aba, Veli. “Duygusal Yakınlık Bağlamında Nesnel Cerh Uygulama Örnekleri (Baba-Oğul/HocaTalebe Özelinde)". Din Bilimleri Akademik Araştırma Dergisi 16/2 (Haziran 2016), 125-156.

Acun, Fatma. “Tarihte Objektiflik Tartışması”. Muhafazakar Düşünce 7/2 (2006), 109-125.

Ahmed b. Hanbel, Ebû Abdillâh Ahmed b. Muhammed b. Hanbel eş-Şeybânî el-Mervezî. el-Müsned. thk. Şu'ayb el-Arnaût - 'Adil Mürşid. b.y.: Mü' essesetü'r-Risâle, 1421/2001.

Ahmed b. Hanbel, Ebû Abdillâh Ahmed b. Muhammed b. Hanbel eş-Şeybânî el-Mervezî. el- 'ilel ve ma 'rifetü'r-ricâl. thk. Vasıyyullah b. Muhammed Abbâs. 3 Cilt. Riyad: Dârü'l-Hâni, 2. Basım, $1422 / 2001$.

Altun, Hilmi Kemal . “Nâsıbî Kavramı Üzerine Tahlil ve Değerlendirme”. Pamukkale Üniversitesi İlahiyat Fakültesi Dergisi (PAÜİFD). $7 / 2$ (Aralık 2020), 1198-1230.

Apaydın, H. Yunus. “Bir Savunma Refleksi Olarak Eleştiri ve Tartışma”. İslâm Düşüncesinde Eleştiri Kültürü ve Tahammül Ahlâkı. ed. Masum Aytepe - Teceli Karasu. 31-36. İstanbul: Ensar Neşriyat, 2019.

A'zam'î, Muhammed Mustafa. Muhaddislerin Hadis Tenkit Yöntemi. çev. M. Enes Topgül - M. İkbal Aslan. İstanbul: Beka Yayınları, 2017.

el-Buhârî, Ebû Abdillâh Muhammed b. İsmâîl b. İbrâhîm el-Cu'fî el-. et-Târîhu'l-kebîr. thk. Muhammed Abdü'l-Muîd Han. 8 Cilt. Haydarâbâd: Dârü'l-Maârifi'l-Osmâniyye, ts.

el-Buhârî, Ebû Abdillâh Muhammed b. İsmâîl b. İbrâhîm el-Cu'fî. el-Câmiu's-sahîh. nşr. Muhammed Züheyr b. Nâsır en-Nâsır. 9 Cilt. Beyrût: Dârü Tavki'n-Necât, 1422/2001.

Carr E. H. - Fontana J.. Tarih Yazımında Nesnellik ve Yanlılık. çev. Özer Ozankaya. Ankara: İmge Kitabevi, 1992.

Dağıstan, Umut. “Sosyal Bilimlerde Nesnellik Olgusu”. Türk \& İslam Dünyası Sosyal Araştırmalar Dergisi / The Journal of Turk \& Islam World Social Studies 4/14 (Aralık 2017), 450-460.

Dârekutnî, Ebü'l-Hasen Ali b. Ömer. Suâlâtü Hamza'bni Yûsufes-Sehmîli'd-Dârekutnîve ğayrihî mine'lmeşâyih fi'l-cerh ve't-ta'dîl. thk. Muvaffak b. Abdillah b. Abdilkâdir. Riyad: Mektebetü'l-Me'ârif, 1404/1984.

Ebû Dâvûd, Süleymân b. el-Eş'as b. İshâk es-Sicistânî el-Ezdî. Su'âlâtu Ebî 'Ubeyd Muhammed b. 'Alî b. 'Osmân el-Âcurrî Ebâ Dâvud es-Sicistanî fi'l-cerh ve't-ta'dîl. thk. Muhammed Ali Kâsım el-Ömerî. Medîne-i Münevvere: el-Camiatü'l İslâmiyye, 1403/1983.

Ebû Gudde, Abdulfettâh. Hadis İlminde Cerh ve Ta'dîl. çev. Harun Reşit Demirel. Ankara: Takdim Yayınları, 2019.

Efendioğlu, Mehmet. "Münker". Türkiye Diyanet Vakfi Ansiklopedisi. Erişim 30 Ağustos 2021. https://islamansiklopedisi.org.tr/munker--hadis 
87 Veli Aba - Nuray Korkmaz / Râvî Tenkidinde Objektiflik Üzerine Bir Değerlendirme / An Evaluation of Objectivity in Rāwī's Criticism

Erman, Uğur. “Ehl-İ Hadîs ve Ehl-İ Re’y Arasında Yaşanan Polemiklerin Cerh ve Ta'dîl İlmine, Dönemin Te'lîfâtına ve Sosyal/Beşerî İlişkilere Yansıması (Hicrî III. Asır)". e-Şarkiyat İlmi Araştırmaları Dergisi/Journal of Oriental Scientific Research (JOSR) 9/2 (2017), 990-1010.

Evgin, Abdulkadir. "Sünni Kaynaklara Göre Cafer es-Sâdık'ın Hadisciliği". Dini Araştırmalar 12/35 (2009), 127-142.

el-Ezherî, Ebû Mansûr Muhammed b. Ahmed b. Ezher. Tehzîbü'l-luga. thk. Muhammed Avz Mer'ab. 8 Cilt. Beyrût: Dâru İhyâi't-Turasi'l-Arabî, 2001.

Fayda, Mustafa. "Vâkıdî". Türkiye Diyanet Vakfi İslâm Ansiklopedisi. Erişim 25 Ocak 2021. https://islamansiklopedisi.org.tr/vakidi

el-Fesevî, Ebû Yûsuf Ya'kūb b. Süfyân b. Cüvvân (Cüvân). el-Ma'rife ve't-târîh. thk. Ekrem Ziyâ elÖmerî. 3 Cilt. Beyrût: Müessesetü'r-Risâle, 2. Basım, 1401/1981.

Gözütok, Şakir. "İslâm Âlimlerinin Bağımsız Düşünme Ve Eleştiri Anlayışı -Emevî ve Abbasîler Dönemi-". Turkish Academic Research Review - Türk Akademik Araştırmalar Dergisi [TARR] 5/2 (Haziran 2020), 175-204.

Gülşen, Hacer. "Tenkit ve Edebi Tenkit" 3 (2003), 77-80. http://acikerisim.iku.edu.tr/handle/11413/250

Halil b. Ahmed, Ebû Abdurrahman. Kitâbu'l-'Ayn. thk. Mehdî el-Mahzûmî - İbrahim es-Samerrâî. 8 Cilt. Dârü Mektebetü'l-Hilâl, ts.

Hatîb el-Bağdâdî, Ebû Bekr Ahmed b. Alî b. Sâbit. Târîhu Bă̆dâd. thk. Beşşâr Avvâd Ma'rûf. 16 Cilt. Beyrût: Dâru'l-Garbi'l-İslâmî, 1422/2002.

Hatiboğlu, Mehmed Said. İslami Tenkid Zihniyeti ve Hadis İlminin Doğuşu. Ankara: Otto Yayınları, 2. Basım, 2016.

İbn Adî, Ebû Ahmed Abdullāh b. Adî b. Abdillâh el-Cürcânî. el-Kâmil fî du 'afâ 'i'r-ricâl. thk. 'Adil Ahmed Abdulmevcûd - Ali Muhammed Muavvız. 9 Cilt. Beyrût-Lübnân: el-Kütübü'l-'İlmiyye, 1418/1997.

İbn Dakîkul'îd, Ebü'l-Feth Takıyyüddîn Muhammed b. Alî b. Vehb el-Kuşeyrî. el-ìktirâh fì beyâni'lıstlâh ve mâ üdîfe ilâ zâlike mine'l-ehâdîsi'l-ma 'dûde mine's-sihâh. Beyrût: Dârü'l-Kütübü'l-İlmiyye, ts.

İbn Ebû Hâtim, Ebû Muhammed Abdurrahmân b. Muhammed b. İdrîs er-Râzî. el-Cerh ve't-ta'dîl. 9 Cilt. Beyrût: Dârü İhyâi't-Türâsi'l-Arabî, 1952.

İbn Hacer, Ebu'l-Fadl Ahmed b. Ali b. Muhammed b. Ahmed b. Hacer el-Askalâni. Nüzhetü'n-nazar fî tavzîhi Nuhbeti'l-fiker fî mustalahi ehli'l-eser. thk. Abdullah b. Dayfullah er- Râhilî. Riyad: Matbaatü Sefîr, 1422.

İbn Hibbân, Ebû Hâtim Muhammed b. Hibbân b. Ahmed el-Büstî. el-Mecrûhîn mine'l-muhaddisîn ve'd-duafâ ve' l-metrûkîn. thk. Mahmûd İbrâhim Zâyed. 3 Cilt. Halep: Dâru'l-Vâî, 1396. 
İbn Manzûr, Cemâleddîn Muhammed b. Mükerrem b. Alî b. Ahmed el-Ensârî. Lisânü'l- 'Arab. 15 Cilt. Beyrût: Dârü Sadr, ts.

İbn Manzûr, Ebü'l-Fazl Cemâlüddîn Muhammed b. Mükerrem b. Alî b. Ahmed el-Ensârî erRüveyfîi. Muhtasaru Târîhi Dımaşk. nşr. Rûhiyye en-Nehhâs vd. 29 Cilt. Dimaşk - Suriye: Dâru'lFikr, 1402/1984.

İbn Sa'd, Ebû Abdillâh Muhammed b. Sa'd b. Menî‘ el-Kâtib el-Hâşimî el-Basrî el-Bağdâdî. etTabakâtü'l-kübrâ. thk. Muhammed Abdülkâdir Atâ. 8 Cilt. Beyrût: Dârü'l-Kütübi'l-İlmiyye, 1410/1990.

İbnu's-Salah, Ebû Amr Takıyyüddîn Osmân b. Salâhiddîn Abdirrahmân b. Mûsâ. Mukaddimetü İbni's-Salâh. thk. Nûreddin Itr. Sûriye -Beyrût: Dârü'l-Fikr-Dârü'l-Fikri'l-Muâsır, 1406/1986.

Kâdî İyâz, Ebü'l-Fazl İyâz b. Mûsâ b. İyâz el-Yahsubî. el-İlmâ' ilâ ma 'rifeti usûli'r-rivâye ve takyîdi'ssemâ'. thk. Seyyid Ahmed Sakr. Kahire-Tunus: Dârü't-Türâs-Mektebetu'l-Atîka, 1379/1970.

Kâdî İyâz, Ebü'l-Fazl İyâz b. Mûsâ b. İyâz el-Yahsubî. Tertîbü'l-medârik ve takrîbü'l-mesâlik. thk. Muhammed b. Tâvît et-Tancî vd. 8 Cilt. Mağrib: Matbaatü Fedâle-el-Muhammediyye, 1965, 1966, 1970, 1981, 1983.

Kahraman, Hüseyin. "Hadis Şerhinde Mezhep Faktörü". Usul İslam Araştırmaları Dergisi $7 / 7$ (2007), 7-34 (Erişim 28 Mart 2021). https://dergipark.org.tr/en/download/article-file/153805

Kamer, Eymen. “Akran Râvî Tenkîdinin Değeri”. Hadis Tetkikleri Dergisi 18/2 (2020), 113-130.

Kanarya, Bayram. “Cerh-Ta'dîl Bağlamında İmam Şafî̂̀ye Yöneltilen İthamlar”. Hitit Üniversitesi İlahiyat Fakültesi Dergisi 16/31 (2017), 227-244.

Karahan, Abdullah. “Türkiye' de Cerh ve Ta'dîl ile Alakalı Yapılmış Çalışmalar”. Uludă̆ Üniversitesi İlâhiyat Fakültesi 13/2 (2004), 183-196.

Karahan, Abdullah. “İbn Hazm’ın Râvi Tenkidinde Eleştirilen Yönlerinin Onun Tenkitçi Kimliğine Etkisi: el-Muhallâ Çerçevesinde Değerlendirme”. Uludă̆ Üniversitesi İlahiyat Fakültesi Dergisi 16/1 (2007), 121-152.

el Kevserî, Zâhid. Te'nîbü'l-Hatîb 'alâ mâ sâkahû fî tercemeti Ebî Hanîfe mine'l-ekâzîb. b.y.: y.y., 1410/1990.

Kur'ân Yolu. Erişim 9 Mayıs 2021. https:/ / kuran.diyanet.gov.tr

el-Leknevî, Ebu'l-Hasenât Muhammed Abdülhay b. Muhammed Abdilhalîm b. Muhammed Emînillâh es-Sihâlevî. er-Ref' ve't-tekmîl fi'l-cerh ve't-ta 'dîl. thk. Abdulfettah Ebû Gudde. Halep: Mektebetü'l-Matbûati'l-İslâmiyye, 3. Basım, 1407.

el-Leknevî, Abdulhay. Hadis Değerlendirme Kriterleri. çev. Mahmut Yazıcı. Ankara: Takdim Yayınları, 2019.

el-Mizzî ,Ebü'l-Haccâc Cemâlüddîn Yûsuf b. Abdirrahmân b. Yûsuf. Tehzîbü'l-Kemâl fî esmâ'i'r-ricâl. thk. Beşşâr Avvâd Ma'rûf. 35 Cilt. Beyrût: Müessesetü'r-Risâle, 1400/1980. 
89 Veli Aba - Nuray Korkmaz / Râvî Tenkidinde Objektiflik Üzerine Bir Değerlendirme / An Evaluation of Objectivity in Rāwī's Criticism

el-Müslim, Ebü'l-Hüseyn Müslim b. el-Haccâc el-Kuşeyrî. Câmiu's-sahîh. thk. Muhammed Fuâd Abdulbâkî. 5 Cilt. Beyrût: Dârü İhyâi't-Turâsi'l-Arabî, ts.

en-Nesâî, Ebû Abdirrahmân Ahmed b. Şuayb b. Alî. ed-Du 'afấ' ve'l-metrûkîn. thk. Mahmûd İbrâhim Zâyed. Halep: Dârü'l-Vâî, 1396.

Önkal, Ahmet. “İslam Tarihçiliğinde Tarafsızlık Problemi”. Marife Dergisi 5/1 (2005), 253-265.

Öz, Mustafa. "Nâsıbe". Türkiye Diyanet Vakfi İslâm Ansiklopedisi. Erişim 9 Kasım 2021. https://islamansiklopedisi.org.tr/nasibe

Parlatır, İsmail vd. Türkçe Sözlük. Ankara: Türk Dil Kurumu, 9. Basım, 1998.

Polat, Salahattin. Hadis Araştırmaları: Tarih, Usûl, Tenkid, Yorum. Kayseri: Kimlik Yayınları, 6. Basım, 2017.

Polat, Salahattin vd. Hadis Araştırma ve Tenkit Kılavuzu. İstanbul: MÜ İlâhiyat Fakültesi Vakfı Yayınları, 6. Basım, 2018.

Sandıkçı, Kemal. "Ahmed b. Sâlih et-Taberî". Türkiye Diyanet Vakfi İslâm Ansiklopedisi. Erişim 20 Haziran 2021. https:/ / islamansiklopedisi.org.tr/ahmed-b-salih-et-taberi

es-Serahsî, Ebû Bekr Şemsü'l-eimme Muhammed b. Ebî Sehl Ahmed. Şerhu's-Siyeri'l-kebîr. b.y.: Şirketu'ş-Şarkıyyetu'l-ìlânât, 1971.

Severcan, Şefaettin. “Rivayetlerin Bilimselliği: Hz. Peygamber ve Dört Halife Dönemi”. İSTEM 5/9 (2007), 21-36.

es-Sübkî, Ebû Nasr Tâcüddîn Abdülvehhâb b. Alî b. Abdilkâfî. Kâide fi'l-cerh ve't-ta'dîl. thk. Abdulfettâh Ebû Gudde. Beyrût: Dâru'l-Beşâir, 5. Basım, 1410/1990.

es-Sübkî, Ebû Nasr Tâcüddîn Abdülvehhâb b. Alî b. Abdilkâfî. Tabakâtü'ş-Şâfiiyyeti'l-kübrâ. thk. Mahmûd Muhammed et-Tanâhî - Abdülfettâh Muhammed el-Hulv. 10 Cilt. Kahire: Dâru Hicr, 2. Basım, 1413.

Şemseddin Sâmi. Kâmûsıı Türkî. nşr. Ahmed Cevdet. Dersaadet: İkdâm Matbaası, 1317.

Tatlı, Bekir. "Hadis Usulünde Râvi ve Rical Tenkidinin Teolojik Temelleri”. Çukurova Üniversitesi İlahiyat Fakültesi Dergisi (ÇÜİFD) 20/2 (2020), 410-434. https://doi.org/10.30627/cuilah.740434

Topaloğlu, Nuri. “İbn Mâkûlâ”. Türkiye Diyanet Vakfi İslâm Ansiklopedisi. Erişim 22 Mart 2021. https://islamansiklopedisi.org.tr/ibn-makula

Topgül, Muhammed Enes. Rivayetten Râviye: Cerh-Ta' dîl Hükümleri Nasıl Oluştu? İstanbul: Marmara Üniversitesi İlahiyat Fakültesi Vakfı Yayınları, 2019.

Turhan, Halil İbrahim. Ricâl Tenkidinin Doğuşu ve Gelişimi: Hicrî ilk İki Asır. İstanbul: MÜ İlahiyat Fakültesi Yayınları, 2015.

Uğur, Mücteba. Ansiklopedik Hadis Terimleri Sözlüğü. Ankara: Türkiye Diyanet Vakfı, 2. Basım, 2018. el-Ukaylî, Ebû Ca' fer Muhammed b. Amr b. Mûsâ. ed-Du 'afầ' ü'l-kebîr. thk. Abdülmu'tî Emîn Kal'acî. 4 Cilt. Beyrût: Dârül'l-Mektebeti'l-İlmiyye, 1404/1984. 
Ünal, İsmail Hakkı. İmam Ebu Hanife' nin Hadis Anlayışı ve Hanefi Mezhebinin Hadis Metodu. Ankara: Diyanet İşleri Başkanlığı, 4. Basım, 2012.

Yahyâ b. Maîn, Ebû Zekeriyyâ Yahyâ b. Maîn b. Avn el-Mürrî el-Bağdâdî. Su'âlâtü İbni'l-Cüneyd li Eb̂̂ Zekeriyyâ Yahyâ b. Maîn. thk. Ahmed Muhammed Nûrseyf. Medîne-i Münevvere: Mektebetü'd-Dâr, 1408/1988.

Yâkūt el-Hamevî, Ebû Abdillâh Şihâbüddîn Yâkūt b. Abdillâh el-Hamevî el-Bağdâdî er-Rûmî. Mu 'cemü'l-üdebâ': İrşâdü'l-erîb ilâ ma 'rifeti'l-edîb. thk. İhsan Abbas. 7 Cilt. Beyrût: Dâru'l-Garbi'lİslâmî, 1414/1993.

Yıldırım, Enbiya. Hadis İlminin İncelikleri. İstanbul: Ensar Neşriyat, 2021.

ez-Zebîdî, Muhammed Murtazâ. Tâcü'l- 'arûs min cevâhiri'l-Kâmûs. thk. Mecmûa min Muhakkîkîn. Dârul Hidâye, ts.

ez-Zehebî, Ebû Abdillâh Şemsüddîn Muhammed b. Ahmed b. Osmân. Mîzânü'l-i 'tidâl fî̀nakdi'r-ricâl. thk. Ali Muhammed el-Becâvî. 4 Cilt. Beyrût - Lübnân: Dârü'l-Mârife, 1382/1963.

ez-Zehebî, Ebû Abdillâh Şemsüddîn Muhammed b. Ahmed b. Osmân. el-Mûkıza "fî̀ 'ilmi mustalahi'lhadîs". thk. Abdulfettah Ebû Gudde. Halep: Mektebetü'l-Matbûati'l-İslâmiyye, 2. Basım, 1412.

ez-Zehebî, Ebû Abdillâh Şemsüddîn Muhammed b. Ahmed b. Osmân. er-Ruvâtü's-sikâtel-mütekellem fîhim bimâ lâ yûcibü reddehüm. thk. Muhammed İbrâhim el-Mevs1lî. Beyrût - Lübnân: Daru'lBeşâiri'l-İslâmiyye, 1412/1992.

ez-Zehebî, Ebû Abdillâh Şemsüddîn Muhammed b. Ahmed b. Osmân. Tezkiretü'l-huffâz. 4 Cilt. Beyrût-Lübnân: Dârü'l-Kütübü'l-İlmiyye, 1419/1998.

ez-Zehebî, Ebû Abdullah Muhammed b. Ahmed b. Osman b. Kaymaz. Siyeru a'lâmi'n-nübelâ. ed. Şu'ayb el-Arnaût. Beyrût: Müessesetü'r-Risâle, 1985. 